\title{
The effect of pavement characteristics on pedestrians' thermal comfort in Toronto'
}

\author{
Mohammad Taleghani ${ }^{\star}$, Umberto Berardi
}

\begin{abstract}
Urban heat island (UHI) has proved to have an important effect in urban microclimate of large cities. In particular, the materials used for the pavements of urban spaces and sidewalks affect pedestrians' comfort significantly. Dark materials store solar radiation during the day and re-radiate it overnight. Reversely, cool materials, given their high albedo, are often proposed for mitigating $\mathrm{UHI}$ issues. This paper focuses on the effect on the outdoor thermal comfort of different materials in a main urban square in Toronto. The study is performed at the neighborhood scale, using the high resolution software ENVI-met. Simulations done for a summer heat wave in 2015 allowed to predict the maximum effect of pavements with surfaces having different albedo. The physiological equivalent temperature (PET) is used to assess the pedestrians' thermal comfort. The results show the relative effectiveness of different pavement materials. In particular, thermal comfort evaluations are reported to assess the microclimate benefits of bright marbles over black granites.
\end{abstract}

Key Words: Urban heat island, pavements, cool materials, outdoor thermal comfort, physiological equivalent temperature

\section{INTRODUCTION}

Urban heat island (UHI) is known as the phenomenon that the air temperatures in city centers are higher than suburban (Oke, 2002). This is due to the lack of vegetation and water bodies in the city centers. Moreover, dark surfaces like asphalt pavements cover most of the roads, roofs and urban spaces. Recent studies have shown that the increasing of UHI in cold climates like Moscow (Lokoshchenko, 2014), Stockholm (Thorsson, Lindberg, Björklund, Holmer, \& Rayner, 2011), and Toronto (Berardi \& Wang, 2016) has significant impacts on citizens' health and thermal comfort.

The combination of UHIs and heat waves have caused heat related mortality in different climates. During a 2-week heat wave in August 2003, around 70,000 mortalities were reported in Europe. Toronto Public Health Department has estimated 120 heat related mortality in Toronto per year (Penney, 2008). Furthermore, it is estimated that cooling degree days in Toronto will be increased by plus 239 by 2040 (WTO-UNEP, 2008).

Wang, Berardi, and Akbari (2016) showed that increasing the amount of street vegetation by at least $10 \%$ over the current density of green areas would have a large impact on of the UHI effect. Moreover, combining more vegetation with reflective pavements and roofs together, it would be possible to reduce the average air temperature by up to $0.8^{\circ} \mathrm{C}$ at mid-day and $0.6^{\circ} \mathrm{C}$ at midnight during the hot summer days (Wang et al., 2016). This is in accordance with literature that has often proved that the man maid materials with low albedo, and the lack of vegetation and water bodies in urban spaces contribute to the urban heat islands (Hart \& Sailor, 2009; Sailor, 2014; Taleghani, Kleerekoper, Tenpierik, \& van den Dobbelsteen, 2015; Taleghani, Tenpierik, van den Dobbelsteen, \& Sailor, 2014). Asphalt and concrete surfaces constitute around $40 \%$ of Canadian

\footnotetext{
${ }^{1}$ Portions of this paper has appeared in the $4^{\text {th }}$ IC2UHI Conference in Singapore 2016.

* Corresponding author: Mohammad Taleghani; University of Salford, Manchester, UK m.taleghani@salford.ac.uk

Umberto Berardi; Ryerson University, Toronto, Canada uberardi@ryerson.ca
} 
urban areas (Gui, Phelan, Kaloush, \& Golden, 2007). Krayenhoff et al. (2003) showed that on average, Toronto is covered with $16.2 \%$ asphalt, and $13.7 \%$ concrete. Based on Table 1, asphalt and concrete pavements have low albedos. Consequently, increasing the albedo of these large portion of urban surfaces would be an appropriate strategy for mitigating the UHI effect, substituting dark materials covering urban surfaces with materials with high albedo has been often proposed worldwide (Hashem Akbari \& Konopacki, 2004; H. Akbari, Pomerantz, \& Taha, 2001; Synnefa, Santamouris, \& Akbari, 2007).

Table 1: The albedo of common urban surface materials (Baker \& Canada, 1980; Bretz, Akbari, Rosenfeld, \& Taha, 1992; Oke, 1987; Santamouris, 2012).

\begin{tabular}{|l|l|}
\hline Material & Albedo \\
\hline Asphalt & $0.05-0.2$ \\
\hline Concrete & $0.10-0.35$ \\
\hline Red brick & 0.30 \\
\hline White marble chips & 0.55 \\
\hline Gravel & 0.72 \\
\hline White plaster & 0.93 \\
\hline
\end{tabular}

Taha et al. (1992) simulated the impact of high albedo surfaces and vegetation in streets in Toronto and three other Canadian cities. They could show that by increasing the vegetative fraction by $30 \%$, the building energy demand for cooling in Toronto would reduce by $10 \%$ in urban houses and $20 \%$ in suburban areas. Regarding the roof albedo, they showed that implementing 0.2 higher albedo surfaces can reduce the cooling-energy use by about $30-40 \%$. More recently, Taleghani et al. (2014) showed that white roofs (with the albedo of 0.91) increased the globe and mean radiant temperature $\left(0.9{ }^{\circ} \mathrm{C}\right.$ and $2.9^{\circ} \mathrm{C}$ respectively) while the air temperature was reduced by $1.3{ }^{\circ} \mathrm{C}$ compared to a dark pavement (albedo of 0.37 ) in the temperate climate of Portland (OR, USA).

Santamouris et al (2012) looked at the impact of $4500 \mathrm{~m}^{2}$ high albedo materials on the pavement of a park in Athens, Greece. This size of land surface modification to improve pedestrians' thermal comfort is among the largest in the world. They reported that this amount of cool pavements reduced the peak ambient air temperature by up to $1.9^{\circ} \mathrm{C}$, and the ground surface temperature was reduced by $12^{\circ} \mathrm{C}$.

Recently, several studies have been performed to investigate the cooling impact of water spray systems and water ponds on urban open spaces. As an example, Montazeri et al. (2017) used a high resolution CFD model to show the cooling potential of a water spray system on outdoor thermal comfort of pedestrians in Rotterdam, the Netherlands. They showed that the water spray with 15 hollow-cone nozzles could reduce the air temperature and thermal comfort unit (UTCl) by up to 7 and $5{ }^{\circ} \mathrm{C}$, respectively during a heat wave in July 2006. In another study in Shanghai, measurement were done on the spray cooling technology to a pavilion. Similar to the results in the Netherlands, Huang et al. (2011) also showed that the air temperature could be reduced up to $7{ }^{\circ} \mathrm{C}$ while the ambient air temperature is $35^{\circ} \mathrm{C}$ with the relative humidity of $45 \%$.

In this paper, the microclimate of one of the most important urban open spaces in Toronto is studied. The square is covered with a black pavement, and a small water pond exists in there. The simulations were done for the hottest day of 2015 in Toronto. Most of the previous studies on pavement characteristics were done on building roof tops; however, modification of roofs can barely affect pedestrians in city centers with high-rise buildings (Taleghani, Sailor, \& Ban-Weiss, 2016). So, this paper focuses on ground pavement, and answers to the question that how high albedo ground pavements affect pedestrians' thermal comfort. Moreover, the impact of the water pond on pedestrians' comfort will be investigated as a new mitigation strategy. Based on the simulated micrometeorological parameters, physiological equivalent temperature as a human thermal comfort parameter will be calculated to answer the research question. Finally, with the goal to improve the thermal comfort, different heat mitigation strategies will be considered. 


\section{RESEARCH METHOD}

Recent studies have clarified the spatial limits of satellite analysis (like LandSat 8 infrared images with the resolution of $100 \mathrm{~m}^{*} 100 \mathrm{~m}$ ) and mesoscale assessments of the urban environment, and have suggested a combination of these with detailed analyses at the scale of single neighborhoods in order to capture specific urban elements This because mesoscale elaborations ignore the contribution from the building walls and calculate the surface temperatures from the radiated energy in a small spectrum range, suffering thermal anisotropy, while they are unable to take into account the emissivity of the surface materials.

In this paper, the final design of the Yonge-Dundas square (Fig. 1) in Toronto is assessed looking at the microclimate characteristics during the hottest day of the year 2015 (July $28^{\text {th }}$ ). In addition to the evaluation of the square with the final land cover, three scenarios are simulated to assess the possible improvements of the microclimate of the square. The results of the simulations are later used in RayMan (Matzarakis, Rutz, \& Mayer, 2007) to generate and the discuss the Physiological Equivalent Temperature (Höppe, 1999).

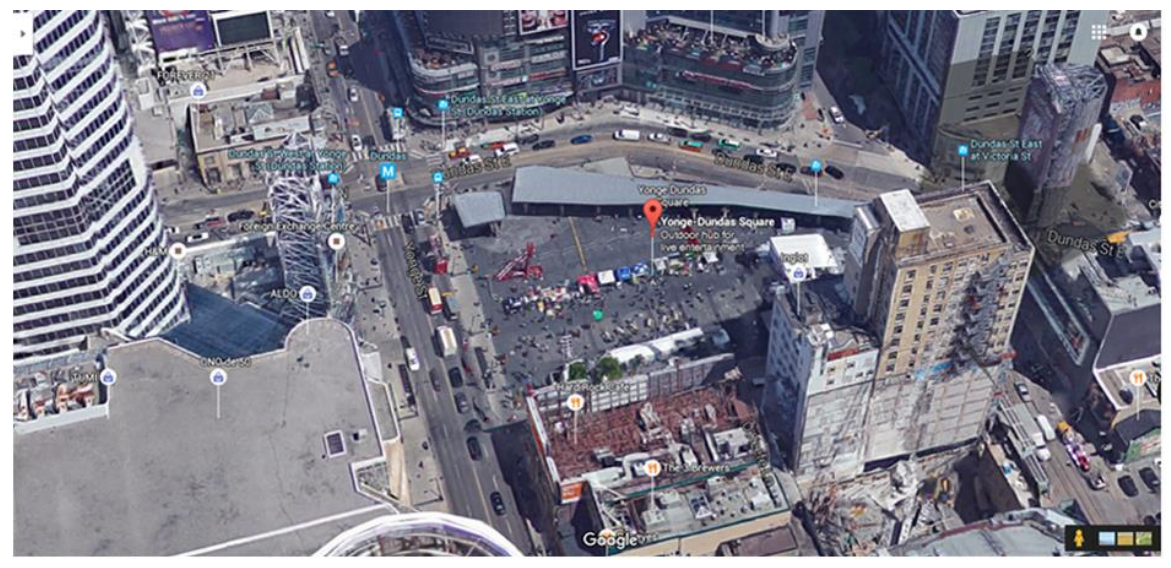

Figure 1: The study area in Toronto: Dundas square photographed from above (top) and the South-East corner (down).

In this research, ENVI-met, a high resolution computational fluid dynamic program, is used. The simulation is done for a full day, using as initial conditions those stated in Table 2. The urban geometries and surface characteristics (land cover) were modeled according to the final design of the square (Fig. 1). The initial weather conditions were extracted from the online historical weather data available on (http://www.wunderground.com/).

Table 2: Conditions used in the reference simulation with ENVI-met.

\begin{tabular}{l|l}
\hline Simulation day & 28.07 .2015 \\
Location & Toronto $\left(43.7^{\circ} \mathrm{N}, 79.4^{\circ} \mathrm{W}\right)$ \\
Simulation period & 24 hours (starting $4: 00 \mathrm{am})$ \\
Spatial resolution & $2 \mathrm{~m}$ \\
Initial air temperature & $22.4^{\circ} \mathrm{C}$ \\
Wind speed (at $2 \mathrm{~m})$ & $1.4 \mathrm{~m} / \mathrm{s}$ \\
Wind direction & $33^{\circ}($ North East) \\
Relative humidity (at $2 \mathrm{~m})$ & $73 \%$ \\
Indoor buildings temperature & $20.0^{\circ} \mathrm{C}$ \\
Heat transmission & $0.38 \mathrm{~W} / \mathrm{m}^{2} \mathrm{~K}$ (walls), $0.24 \mathrm{~W} / \mathrm{m}^{2} \mathrm{~K}$ (roofs) \\
Albedo of the surfaces & 0.2 (walls), 0.1 (roofs), 0.1 (pavements) \\
\hline
\end{tabular}

The increase of using ENVI-met for microclimate modelling has allowed its validation in several recent studies. These studies have done field measurements and either compared the difference in measured and simulated air temperature (Elnabawi, Hamza, \& Dudek, 2013); or showed a correlation coefficient between the two sets of data (Dain Jeong et al., 2015). Among all these studies, Wang et al. (2016) report a validation campaign of ENVI-met model close to those 
investigated in this paper. They validated ENVI-met in three neighborhoods of Toronto. They compared the simulated air temperature within low-rise, mid-rise and high-rise neighborhoods with measured air temperature from a governmental weather station. They reported an average difference of $0.2-1.2{ }^{\circ} \mathrm{C}$ in the winter and $3.1-3.2{ }^{\circ} \mathrm{C}$ in the summer simulations, and found a coefficient of determination $\left(R^{2}\right)$ of $0.60-0.68$ in the winter and $0.66-0.83$ in the summer simulations.

In another study in Toronto, Berardi (2016) compared ENVI-met simulations by a weather station data at the roof of a university building located one block a part from the Yonge-Dundas square. The difference between the simulated air temperature and measured one on the roof was less than $2.5^{\circ} \mathrm{C}$ during the day $\left(15^{\text {th }}\right.$ of August). Moreover, the $\mathrm{R}^{2}$ or correlation between the two sets of data was 0.92 .

\subsection{Simulation scenarios}

In this paper, the base model is named reference model. To improve the microclimate of the square, UHI mitigating models are defined according to the following properties:

- Reference: the model with the actual surface cover assigning to the albedo of the square pavement the value of 0.1 ;

- Albedo 0.3: the albedo of the square is increased from 0.1 to 0.3 ;

- Albedo 0.5: the albedo of the square is increased from 0.1 to 0.5 ;

- Water Pound (WP): a large water pond is added to the reference model in the south side of the square.

\subsection{Calculation of outdoor thermal comfort}

In the UHI mitigating scenarios, a receptor was provided at the center of the square. The micrometeorological factors driven from the simulation scenarios at this receptor point were used to calculate thermal comfort. The aim of this research is to investigate the thermal comfort in urban spaces. Therefore, we used the near ground micrometeorological data of ENVI-met.

To calculate the thermal comfort, RayMan 1.2 was used. This program calculates human thermal comfort based on personal (height, weight, age, sex, clothing, and activity) and climatological (air temperature, wind speed, relative humidity, and mean radiant temperature) factors. Table 3 shows the input data that were used to calculate the thermal comfort at the receptor point in the square.

Table 3: Input data to calculate the thermal comfort by RayMan.

\begin{tabular}{l|l}
\hline Activity & $80 \mathrm{~W}$ (walking) \\
Personal data & $1.75 \mathrm{~m}$ (height), 75kg, 35 years old, male \\
Clothing insulation & $0.5 \mathrm{Clo}$ (summer clothes) \\
\hline
\end{tabular}

\section{RESULTS}

\subsection{The microclimate of the square}

The air temperature, mean radiant temperature and surface temperature of the square at 15:00 are shown in Figure 2. The north and east sides of the square has higher air temperatures at 15:00 because most of the square area is shaded by the southern buildings (Fig.2a). The materials used on the surface of the square is dark granite with the albedo of 0.1 . The effect of direct solar beam and shading is more significant when we look at the surface temperature of the square. The north and east sides of the square have $3.15^{\circ} \mathrm{C}$ higher $\mathrm{T}_{\mathrm{s}}$ than the rest of the square area (Fig.2b). There are some trees along the south side of the square, and $T_{s}$ resulted much lower in the adjacent of these trees. The maximum cooling effect of these trees on $T_{s}$ is $12.6{ }^{\circ} \mathrm{C}$, which is in the space between the trees. Looking at the mean radiant temperature, which has a significant effect on human thermal comfort (Kántor \& Unger, 2011), $\mathrm{T}_{\text {mrt }}$ in the square is between 64.0 and $69.0{ }^{\circ} \mathrm{C}$ (Fig. 2c). The effect of some trees on $\mathrm{T}_{\mathrm{mrt}}$ is significant and causes up to $30^{\circ} \mathrm{C}$ cooling effect. 


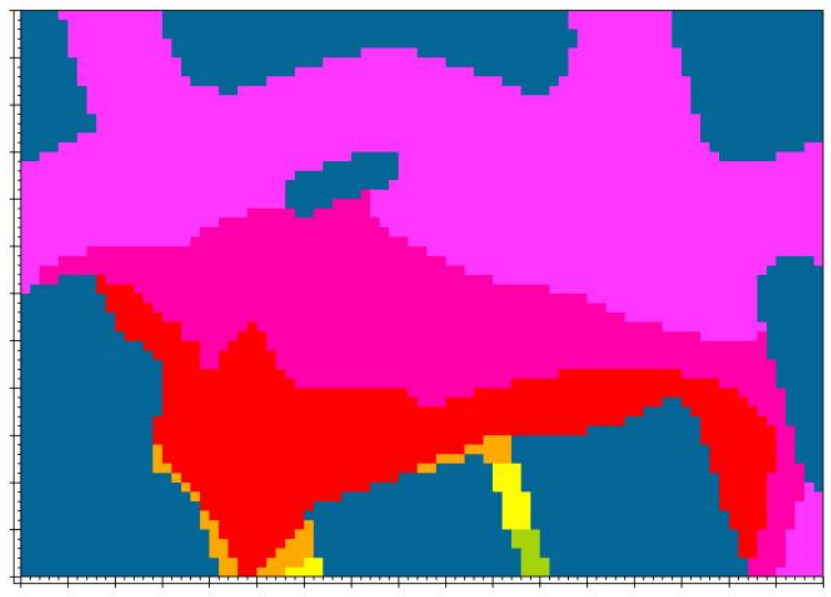

\section{Air Temperature}

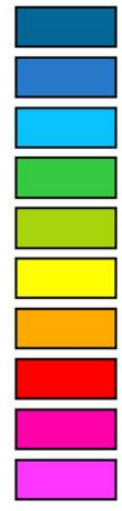

below $30.00{ }^{\circ} \mathrm{C}$

30.00 to $31.00^{\circ} \mathrm{C}$

31.00 to $32.00^{\circ} \mathrm{C}$

32.00 to $33.00^{\circ} \mathrm{C}$

33.00 to $34.00{ }^{\circ} \mathrm{C}$ 34.00 to $35.00^{\circ} \mathrm{C}$ 35.00 to $36.00^{\circ} \mathrm{C}$ 36.00 to $37.00^{\circ} \mathrm{C}$ 37.00 to $38.00^{\circ} \mathrm{C}$ above $38.00^{\circ} \mathrm{C}$

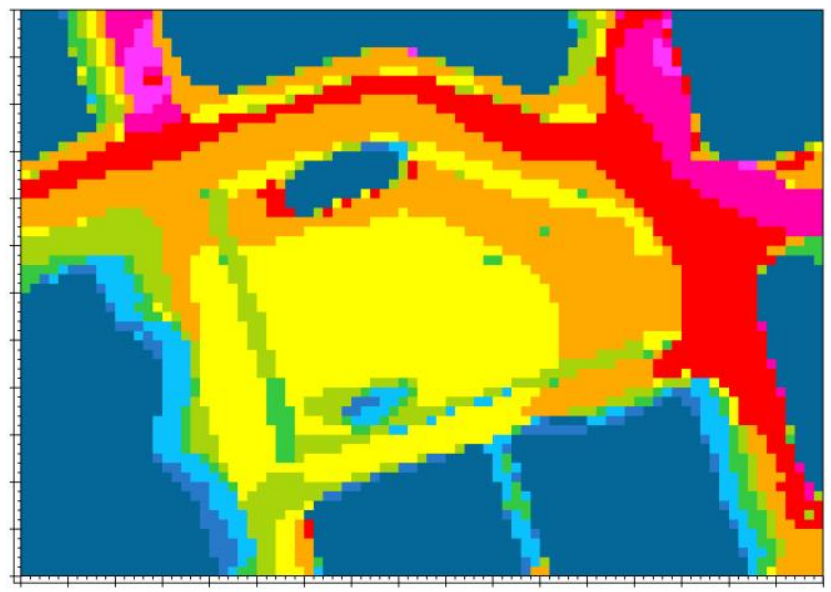

\section{Surface Temperature}

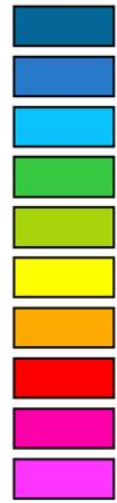

below $32.89^{\circ} \mathrm{C}$ 32.89 to $36.04^{\circ} \mathrm{C}$ 36.04 to $39.19^{\circ} \mathrm{C}$ 39.19 to $42.35^{\circ} \mathrm{C}$ 42.35 to $45.50^{\circ} \mathrm{C}$ 45.50 to $48.65^{\circ} \mathrm{C}$ 48.65 to $51.81^{\circ} \mathrm{C}$ 51.81 to $54.96^{\circ} \mathrm{C}$ 54.96 to $58.11^{\circ} \mathrm{C}$ above $58.11^{\circ} \mathrm{C}$

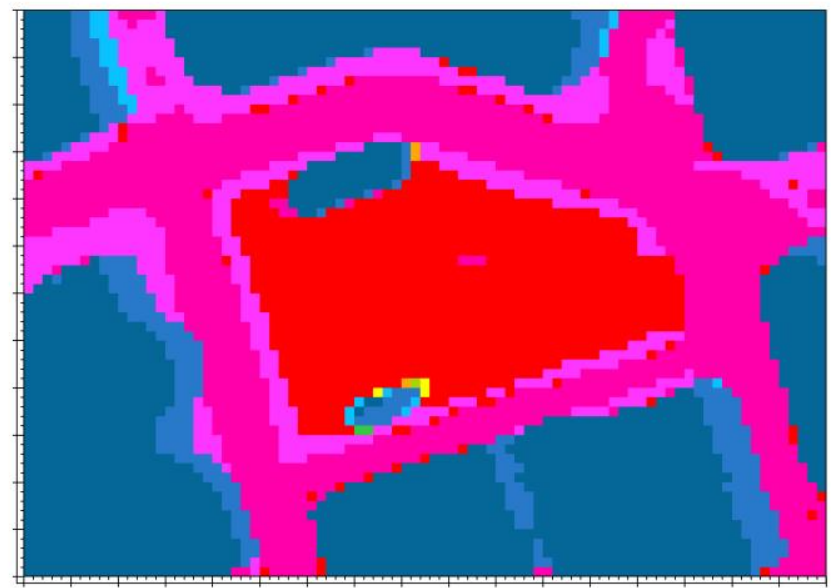

Mean Radiant Temperature

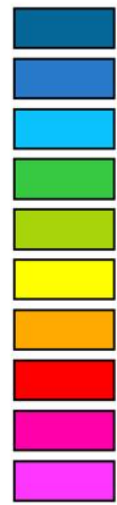

below $34.00^{\circ} \mathrm{C}$ 34.00 to $39.00^{\circ} \mathrm{C}$ 39.00 to $44.00^{\circ} \mathrm{C}$ 44.00 to $49.00^{\circ} \mathrm{C}$ 49.00 to $54.00^{\circ} \mathrm{C}$ 54.00 to $59.00^{\circ} \mathrm{C}$ 59.00 to $64.00^{\circ} \mathrm{C}$ 64.00 to $69.00^{\circ} \mathrm{C}$ 69.00 to $74.00^{\circ} \mathrm{C}$ above $74.00^{\circ} \mathrm{C}$

Figure 2: Air temperature (a); surface temperature (b); and mean radiant temperature (c) at 15:00 on 28.07.2015.

\subsection{The effect of heat mitigation scenarios}

In the Alb.3 and Alb.5 scenarios, the albedo of the dark granite pavement of the square was increased from 0.1 to 0.3 and 0.5 , respectively. The aim was to increase the reflection of the pavement and to absorb less sun. In WP scenario, a water-pond in the south side of the square was modelled. Since it was not possible to model some actual fountains that pour water, the effect of a large water-pond was assessed in the WP scenario (pound not pouring or spraying). 
Figure $3 \mathrm{a}$ shows the air temperature difference between the reference model and Alb.3 scenario at the height of $0.6 \mathrm{~m}$. In this scenario, the albedo of the square pavement is only increased (not the rest of the model pavements). Therefore, the cooling effect of this albedo increase is visible mostly at the center of the square. The maximum cooling effect is $0.5{ }^{\circ} \mathrm{C}$, and this effect dissipates by reaching the edges of the square. By increasing the albedo from 0.1 (reference model) to 0.5 (Alb.5 scenario), the maximum cooling effect reaches to $1.0^{\circ} \mathrm{C}$. Although the cooling effect in Alb.5 is twice as Alb.3, the spatial distributions of the cooling effect in these two scenarios are similar, and do not exceed the boundaries of the square. Regarding the WP scenario, the maximum cooling effect of the water-pond is $0.5^{\circ} \mathrm{C}$. This cooling effect is spread to the south west of the pond because the wind direction is from the northeast.

a)

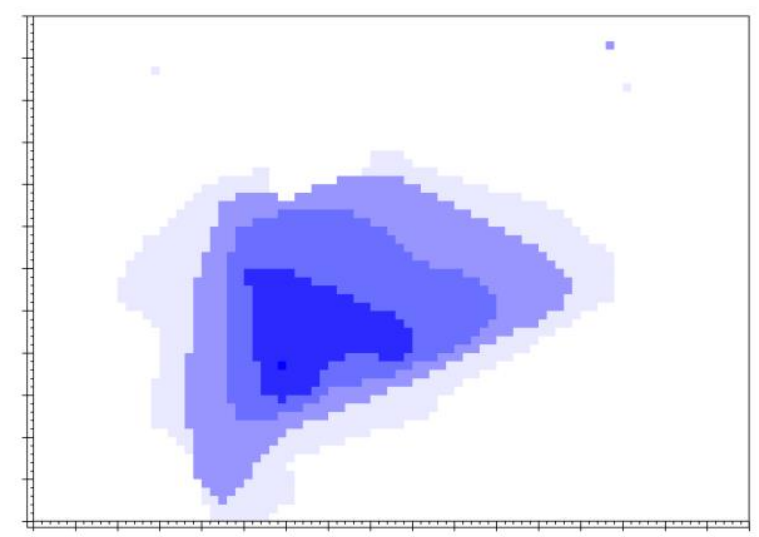

c)

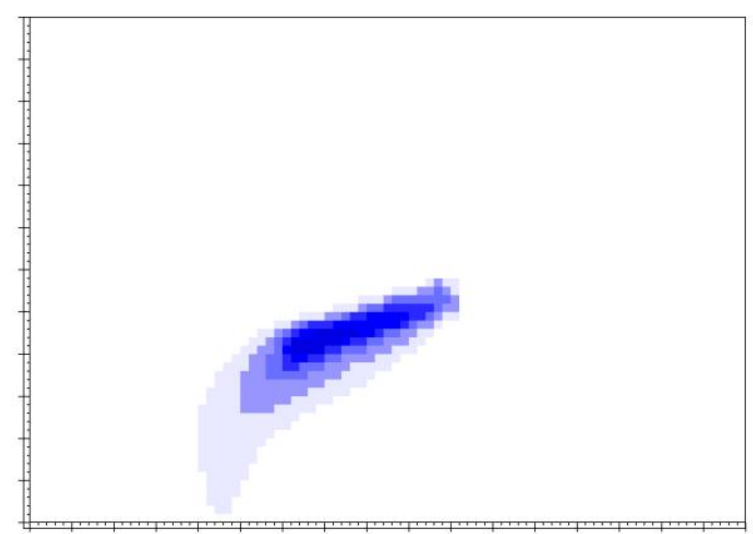

b)

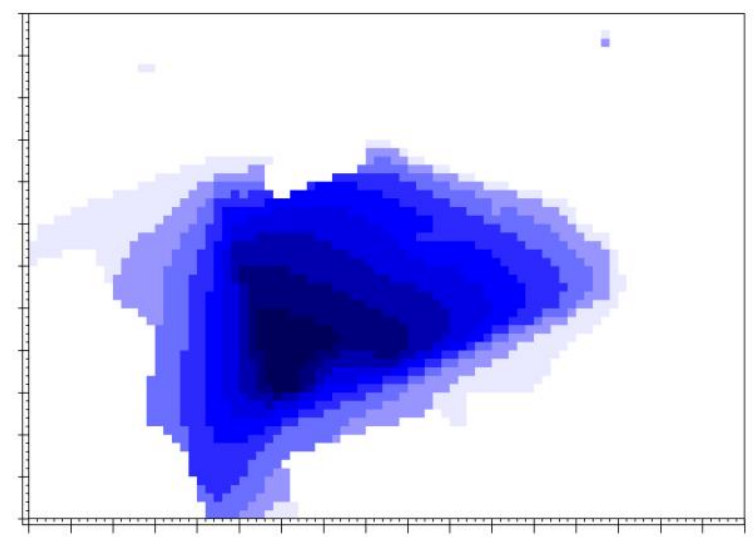

Absolute Different Air Temperature

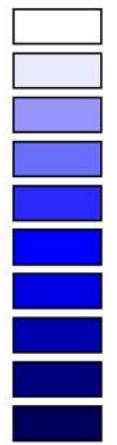

below $0.10^{\circ} \mathrm{C}$

0.10 to $0.20^{\circ} \mathrm{C}$

0.20 to $0.30^{\circ} \mathrm{C}$

0.30 to $0.40^{\circ} \mathrm{C}$

0.40 to $0.50^{\circ} \mathrm{C}$

0.50 to $0.60^{\circ} \mathrm{C}$

0.60 to $0.70^{\circ} \mathrm{C}$

0.70 to $0.80^{\circ} \mathrm{C}$

0.80 to $0.90^{\circ} \mathrm{C}$

above $0.90^{\circ} \mathrm{C}$

Figure 3: The air temperature difference between: the reference model and alb.3 (a); the reference model and alb.5 (b); the reference model and WP (c).

Considering the effect of the mitigation scenarios on the mean radiant temperature at the height of $0.6 \mathrm{~m}$, Alb.3 caused an increase of $5.3{ }^{\circ} \mathrm{C}$ in the square (Fig. $4 \mathrm{a}$ ). This increase of mean radiant temperature was expected due to the increase of albedo. In Alb.5 scenario, $\mathrm{T}_{\text {mrt }}$ is increased to $10.3{ }^{\circ} \mathrm{C}$ above the square area (Fig. 4b). Reversely, the WP scenario was the only model that reduced $\mathrm{T}_{\text {mrt, }}$ up to $6.2^{\circ} \mathrm{C}$ (Fig. 4c). 
a)

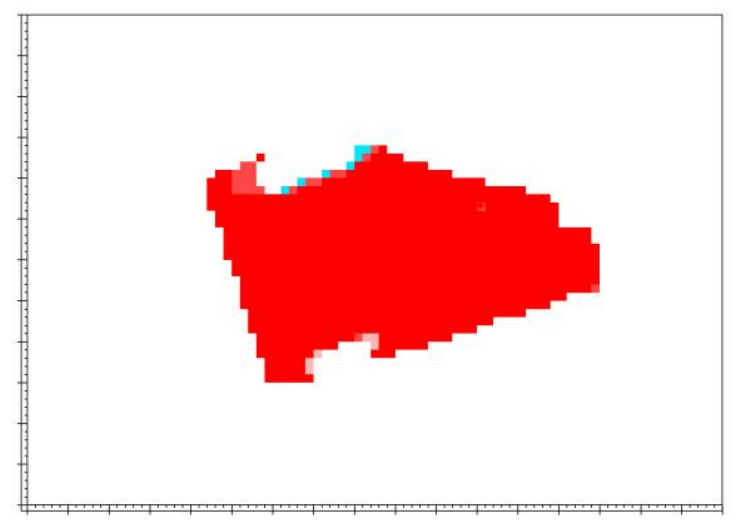

c)

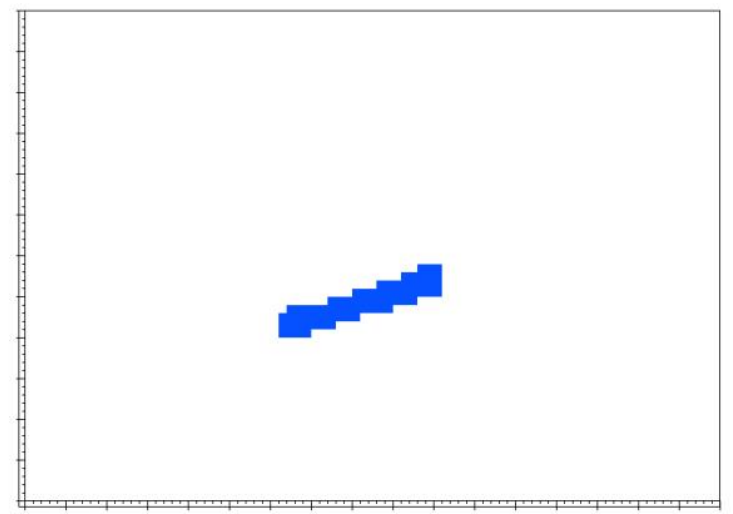

b)

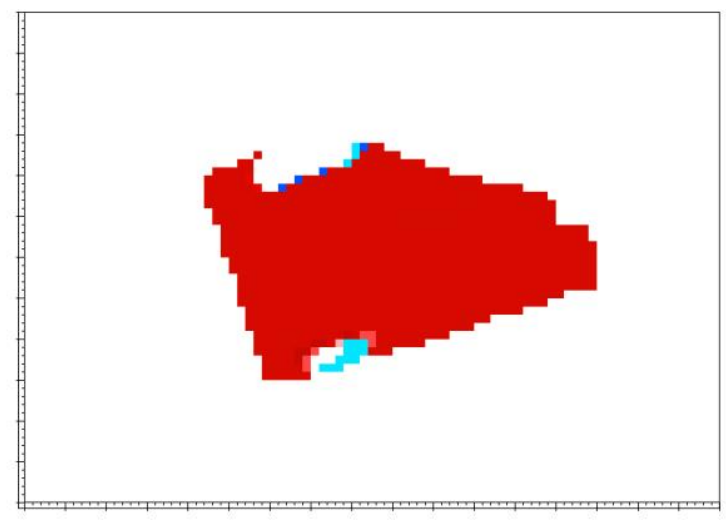

Absolute Different Mean Radiant Temperature

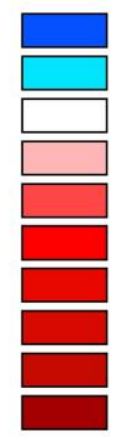

Figure 4: The mean radiant temperature difference between: the reference model and alb.3 (a); the reference model and alb.5 (b); the reference model and WP (c).

\subsection{Thermal comfort in the square}

As mentioned earlier, one of the aims of this study was the comparison of the effect of different heat mitigation strategies on the human thermal comfort within the square. For this scope, the thermal comfort of a 35 year old, male, $75 \mathrm{~kg}$ at the center of the square was calculated. PET was calculated for the four UHI mitigating scenarios (Fig. 5). The minimum PET for all scenarios happened at 5:00, one hour before the sun rise at 6:02. Till this moment, all scenarios had the same PET. After sun rise, Alb.5 showed the maximum PET during the sunlit hours. The reference and WP scenarios had the same PET during the whole day. This shows that the water pond did not affect the receptor point, which is located at the center of the square.

The average PET during the sunlit hours in the reference, Alb.3 and Alb.5 scenarios is 39.6 ${ }^{\circ} \mathrm{C}, 41.5{ }^{\circ} \mathrm{C}$ and $43.4{ }^{\circ} \mathrm{C}$, respectively. At 15:00, all scenarios experienced their maximum PET. Alb.5 and Alb.3 have 4.8 and $2.4{ }^{\circ} \mathrm{C}$ higher PET than the reference scenario. Alb.3 and Alb.5 increased the PET level and reduced the comfort level. Although these two scenarios reduced air temperature (Fig. $3 a$ and $3 b$ ), they increased mean radiant temperature in the square. For instance, Alb.5 scenario decreased $0.5^{\circ} \mathrm{C}$ air temperature, while $\mathrm{T}_{\text {mrt }}$ increased $10.3^{\circ} \mathrm{C}$.

The simulated human body at the receptor point has the clothing rate of 0.5 clo (equal to kneelength short, short-sleeved shirt, and sandal (ASHRAE, 2013). With this low insulation, re-radiation from the reflective ground reduced the thermal comfort. This shows that cool pavements may have negative effects on the pedestrian's thermal comfort. 


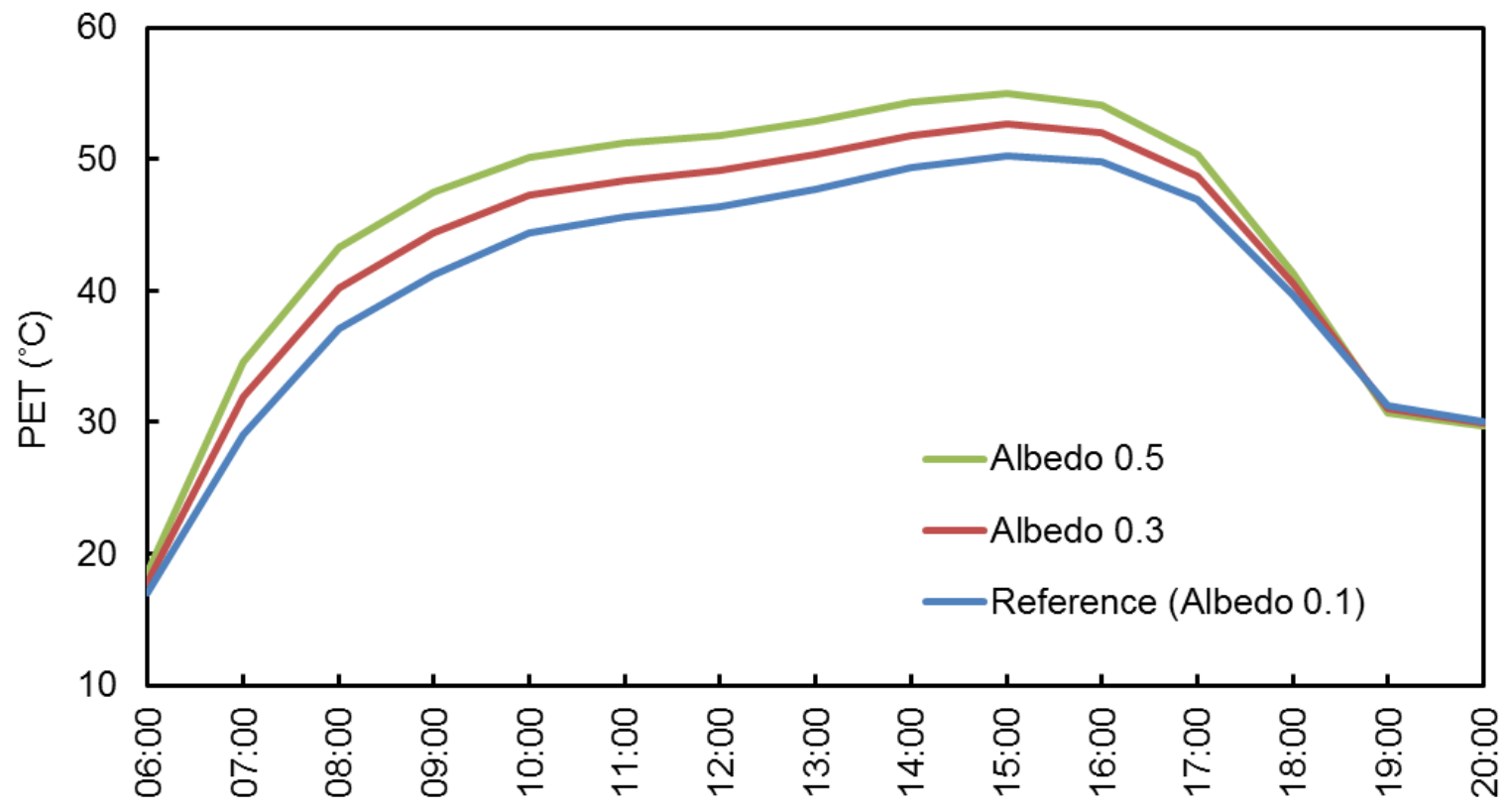

Figure 5: Calculated PET at the center of the square for the different scenarios of pavements.

Figure 6 illustrates the vertical profile of air temperature, mean radiant temperature and PET for a pedestrian at the center of the square. These profiles are plotted at 15:00, the hottest hour of the day. Figure 6-a shows that the increase of pavement albedo reduces the air temperature. Moreover, it should be noted that the slope of vertical air temperatures indicates the effect of surface characteristics on the microclimate. Because of the heat capacity of the pavement, the near surface $(z=0.2 \mathrm{~m})$ air temperature is higher than higher altitudes $(z=1.8 \mathrm{~m})$. The air temperature difference between $0.2 \mathrm{~m}$ and $1.8 \mathrm{~m}$ height is $0.53{ }^{\circ} \mathrm{C}, 0.40{ }^{\circ} \mathrm{C}$ and $0.27{ }^{\circ} \mathrm{C}$ for the reference, Alb.3 and Alb.5 scenarios, respectively. This confirms that a higher albedo causes cooler above air temperature. Figure 6-b shows the vertical profile of PET. This figure shows thermal comfort is mostly affected by the radiation factor rather than by the air temperature. Moreover, similar to the vertical profile of air temperature, the PET vertical change from near surface to $1.8 \mathrm{~m}$ height is higher for the reference model compared to the other scenarios. This difference is $0.6,0.5$ and $0.4{ }^{\circ} \mathrm{C}$ for the reference, Alb. 3 and Alb. 5 scenarios, respectively. 

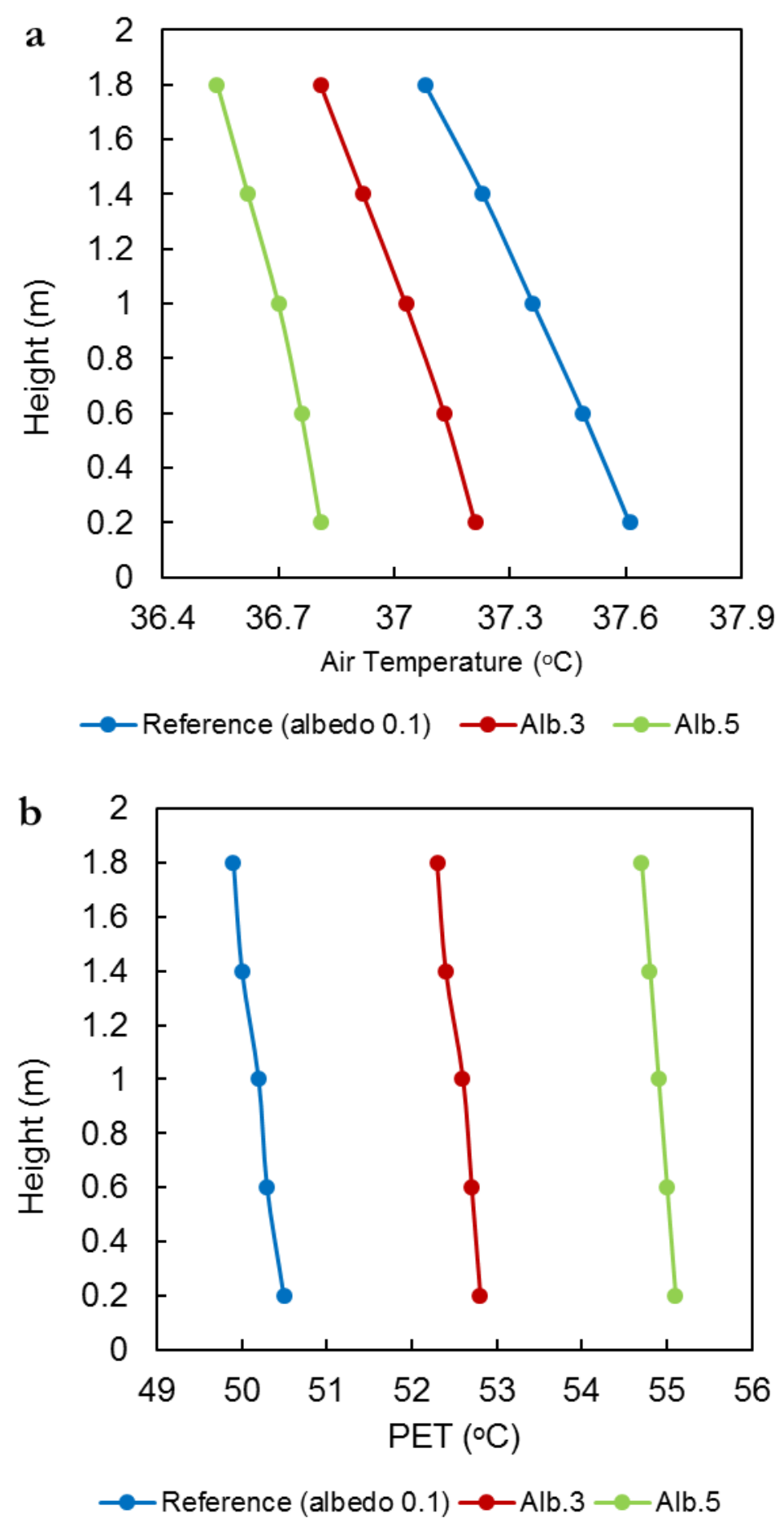

Figure 6: Vertical profile of air temperature (a), mean radiant temperature (b) and PET (c) at the center of the square at 15:00.

To discuss the effect of the water pond on thermal comfort, we added an extra receptor to the WP scenario. Figure 7 shows the comparison of PET at the center of the square, and at the edge of the water pond. The average PET at the center is $1.9^{\circ} \mathrm{C}$ higher than the water pond. This difference reaches the maximum PET at the center of the square to $50.6{ }^{\circ} \mathrm{C}$ at $15: 00$ while PET is $47.0{ }^{\circ} \mathrm{C}$ above the pond. 


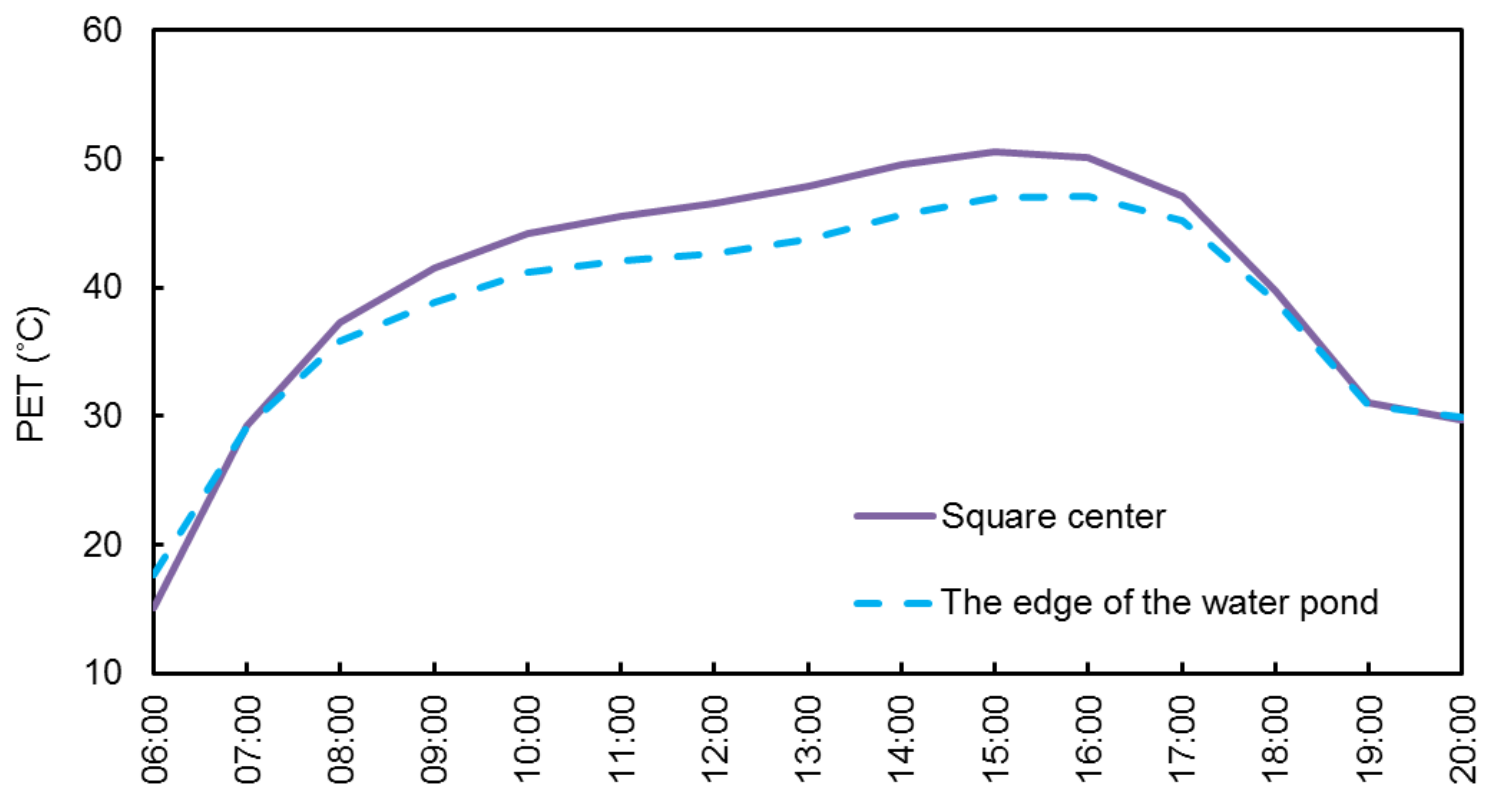

Figure 7: Comparison of PET at the center of the square and at the edge of the water pond in the WP scenario.

\section{DISCUSSION}

Previous studies had shown the impacts of high albedo materials on indoor and outdoor environment. Until today, most of the studies have assessed the application of these materials on roofs. However, fewer studies have focused on the impact of the ground pavement, which is closer to pedestrian level, on outdoor thermal comfort.

This paper focused on a busy urban open space in Toronto with a black pavement. By implementing different heat mitigation strategies, the impact of each scenario on the thermal comfort a pedestrian within the center of the square was assessed. When the albedo of the pavement was increased (from 0.1 to 0.5 ), it was assumed that high reflective materials are replaced with the existing black pavement in the square.

The results showed that air temperature at the height of $1.0 \mathrm{~m}$ is reduced up to 0.66 ${ }^{\circ} \mathrm{C}$ (comparing the reference scenario (albedo 0.1) with the higher albedo of 0.5 . This reduction in air temperature occurred because of the higher reflectivity of the new surface material. The new material re-radiated the incoming solar radiation to the sky. Through this exchange of solar radiation, a pedestrian perceives more radiation. As a result, mean radiant temperature at the height of $1.0 \mathrm{~m}$ is increased up to $10.53{ }^{\circ} \mathrm{C}$. This higher mean radiant temperature affected human thermal comfort directly, and led to an increase of PET by $4.7^{\circ} \mathrm{C}$. In other words, although the higher albedo surfaces reduced near surface air temperatures, they decrease thermal comfort situation for pedestrians. In contrast, the water pond reduced PET by up to $3.6^{\circ} \mathrm{C}$. This finding showed that water ponds and water sprays could be promising strategies to mitigate heat in climates that are not dealing with water shortage. It is recommended for future studies to investigate the different forms of implementing water in urban spaces. These forms could be water sprays or water ponds in different positions within an urban open space.

\section{CONCLUSIONS}

In this paper, we investigated the impact of pavement characteristics in an open space on the thermal comfort of pedestrians. We focused on near ground microclimate condition because it affects human thermal comfort in urban open spaces. The study was performed for the hottest day 
of the year, July $28^{\text {th }} 2015$. The simulation of the square showed that the asphalt pavement with a low albedo makes the microclimate warm by high heat absorption during the day. We used three UHI mitigating scenarios to alter the land cover and consequently reduce the heat in the square. Increasing the albedo of the square from 0.1 to 0.3 and 0.5 made the square 0.5 and $1.0{ }^{\circ} \mathrm{C}$ cooler at 15:00, respectively. Although these two scenarios reduced the air temperature, they increased the solar re-radiation to the pedestrians. This reduced the thermal comfort of pedestrians. In another scenario, we added a water pond to the square, and it reduced the air temperature $0.5{ }^{\circ} \mathrm{C}$ above the pond, and did not affect the thermal comfort situation at the center of the square. Finally, this research showed that although the increase of reflectivity of pavement reduces the air temperature, it reduces the thermal comfort at the pedestrian level. Future works will address the effect of other mitigation strategies on human comfort in public spaces in cold climates.

\section{REFERENCES}

Akbari, H., \& Konopacki, S. (2004). Energy effects of heat-island reduction strategies in Toronto, Canada. Energy, 29(2), 191-210. doi:http://dx.doi.org/10.1016/j.energy.2003.09.004

Akbari, H., Pomerantz, M., \& Taha, H. (2001). Cool surfaces and shade trees to reduce energy use and improve air quality in urban areas. Solar Energy, 70(3), 295-310. doi:http://dx.doi.org/10.1016/S0038-092X(00)00089-X

ASHRAE. (2013). ASHRAE Standard 55-2013 Thermal Environmental Conditions for Human Occupancy. Atlanta, GA: ASHRAE

Baker, M. C., \& Canada, N. R. C. o. (1980). Roofs: design, application, and maintenance: Multiscience Publications.

Berardi, U. (2016). The outdoor microclimate benefits and energy saving resulting from green roofs retrofits. Energy and Buildings, 121, 217-229. doi:http://dx.doi.org/10.1016/j.enbuild.2016.03.021

Berardi, U., \& Wang, Y. (2016). The Effect of a Denser City over the Urban Microclimate: The Case of Toronto. Sustainability, 8(8), 822.

Bretz, S., Akbari, H., Rosenfeld, A. H., \& Taha, H. (1992). Implementation of Solar Reflective Surfaces: Materials and Utility Programs. Retrieved from University of California, Berkeley:

Dain Jeong, Kyunghun Park, Bonggeun Song, Gyeongah Kim, Chulhyun Choi, \& Moon, B. (2015). Validation of ENVI-met PMV values by in-situ measurements. Paper presented at the ICUC9 9th International Conference on Urban Climate jointly with 12th Symposium on the Urban Environment, Toulouse, France.

Elnabawi, M. H., Hamza, N., \& Dudek, S. (2013). Use and evaluation of the ENVI-met model for two different urban forms in Cairo, Egypt: Measurements and model simulations. Paper presented at the 13th Conference of International Building Performance Simulation Association, Chambéry, France.

Gui, J. G., Phelan, P. E., Kaloush, K. E., \& Golden, J. S. (2007). Impact of Pavement Thermophysical Properties on Surface Temperatures. Journal of Materials in Civil Engineering, 19(8), 683-690. doi:doi:10.1061/(ASCE)0899-1561(2007)19:8(683)

H. Taha, D. Sailor, \& Akbari, H. (1992). High-albedo materials for reducing building cooling energy use (LBL-31721; Other: ON: DE93001574 United States10.2172/7000986Other: ON: DE93001574Mon Jun 30 08:46:55 EDT 2008OSTI; NTIS; GPO Dep.LBNL; EDB-92166237; NTS-93-002851English). Retrieved from http://www.osti.gov/scitech//servlets/purl/7000986-lpoimS/

Hart, M., \& Sailor, D. (2009). Quantifying the influence of land-use and surface characteristics on spatial variability in the urban heat island. Theoretical and Applied Climatology, 95(3-4), 397-406. doi:10.1007/s00704-008-0017-5

Höppe, P. (1999). The physiological equivalent temperature - A universal index for the biometeorological assessment of the thermal environment. International Journal of Biometeorology, 43(2), 71-75. 
http://www.wunderground.com/.

Huang, C., Ye, D., Zhao, H., Liang, T., Lin, Z., Yin, H., \& Yang, Y. (2011). The research and application of spray cooling technology in Shanghai Expo. Applied Thermal Engineering, 31(17-18), 3726-3735. doi:http://dx.doi.org/10.1016/j.applthermaleng.2011.03.039

Kántor, N., \& Unger, J. (2011). The most problematic variable in the course of humanbiometeorological comfort assessment - the mean radiant temperature. Central European Journal of Geosciences, 3(1), 90-100. doi:10.2478/s13533-011-0010-x

Krayenhoff, E. S., Martilli, A., Bass, B., \& Stull, R. (2003). Mesoscale simulation of urban heat mitigation strategies in Toronto, Canada. Paper presented at the Fifth International Conference on Urban Climate, 1-5 September, Lodz, Poland.

Lokoshchenko, M. A. (2014). Urban 'heat island' in Moscow. Urban Climate, 10, Part 3, 550-562. doi:http://dx.doi.org/10.1016/j.uclim.2014.01.008

Matzarakis, A., Rutz, F., \& Mayer, H. (2007). Modelling radiation fluxes in simple and complex environments - application of the RayMan model. International Journal of Biometeorology, 51(4), 323-334. doi:10.1007/s00484-006-0061-8

Montazeri, H., Toparlar, Y., Blocken, B., \& Hensen, J. L. M. (2017). Simulating the cooling effects of water spray systems in urban landscapes: A computational fluid dynamics study in Rotterdam, The Netherlands. Landscape and Urban Planning, 159, 85-100. doi:http://dx.doi.org/10.1016/j.landurbplan.2016.10.001

Oke, T. R. (1987). Boundary Layer Climates. New York: Routledge.

Oke, T. R. (2002). Boundary Layer Climates: Taylor \& Francis.

Penney, J. (2008). Climate Change Adaptation in the City of Toronto. Retrieved from

Sailor, D. J. (2014). Risks of summertime extreme thermal conditions in buildings as a result of climate change and exacerbation of urban heat islands. Building and Environment, 78(0), 81-88. doi:http://dx.doi.org/10.1016/j.buildenv.2014.04.012

Santamouris, M. (2012). Environmental Design of Urban Buildings: An Integrated Approach: Taylor \& Francis.

Santamouris, M., Gaitani, N., Spanou, A., Saliari, M., Giannopoulou, K., Vasilakopoulou, K., \& Kardomateas, T. (2012). Using cool paving materials to improve microclimate of urban areas - Design realization and results of the flisvos project. Building and Environment, 53, 128-136. doi:http://dx.doi.org/10.1016/j.buildenv.2012.01.022

Synnefa, A., Santamouris, M., \& Akbari, H. (2007). Estimating the effect of using cool coatings on energy loads and thermal comfort in residential buildings in various climatic conditions.

Energy and Buildings, 39(11), 1167-1174. doi:http://dx.doi.org/10.1016/j.enbuild.2007.01.004

Taleghani, M., Kleerekoper, L., Tenpierik, M., \& van den Dobbelsteen, A. (2015). Outdoor thermal comfort within five different urban forms in the Netherlands. Building and Environment, 83, 65-78. doi:http://dx.doi.org/10.1016/j.buildenv.2014.03.014

Taleghani, M., Sailor, D., \& Ban-Weiss, G. A. (2016). Micrometeorological simulations to predict the impacts of heat mitigation strategies on pedestrian thermal comfort in a Los Angeles neighborhood. Environmental Research Letters, 11(2), 024003.

Taleghani, M., Sailor, D. J., Tenpierik, M., \& van den Dobbelsteen, A. (2014). Thermal assessment of heat mitigation strategies: The case of Portland State University, Oregon, USA. Building and Environment, 73, 138-150. doi:http://dx.doi.org/10.1016/j.buildenv.2013.12.006

Taleghani, M., Tenpierik, M., van den Dobbelsteen, A., \& Sailor, D. J. (2014). Heat mitigation strategies in winter and summer: Field measurements in temperate climates. Building and Environment, 81, 309-319. doi:http://dx.doi.org/10.1016/j.buildenv.2014.07.010

Thorsson, S., Lindberg, F., Björklund, J., Holmer, B., \& Rayner, D. (2011). Potential changes in outdoor thermal comfort conditions in Gothenburg, Sweden due to climate change: the influence of urban geometry. International Journal of Climatology, 31(2), 324-335. doi:10.1002/joc.2231 
Wang, Y., Berardi, U., \& Akbari, H. (2016). Comparing the effects of urban heat island mitigation strategies for Toronto, Canada. Energy and Buildings, 114, 2-19. doi:http://dx.doi.org/10.1016/j.enbuild.2015.06.046

WTO-UNEP. (2008). World Tourism Organization and United Nations Environment Programme Climate Change and Tourism - Responding to Global Challenges: ISBN: 978-92-844-12341 